УДК 615.28

\title{
В.А.Янович ${ }^{1}$, Е.С.Мироненко ${ }^{1}$, И.С.Бутенко ${ }^{1}$, П.В.Копылов ${ }^{2}$, И.П.Снеткова ${ }^{2}$, Н.П.Шестопалов ${ }^{2}$, А.Д.Воронцова ${ }^{3}$, М.А.Тарасов ${ }^{4}$, В.М.Русаков ${ }^{5}$
}

\section{ДЕРАТИЗАЦИОННЫЕ МЕРОПРИЯТИЯ В ЕВРЕЙСКОЙ АВТОНОМНОЙ ОБЛАСТИ В ПОСЛЕПАВОДКОВЫЙ ПЕРИОД}

\author{
${ }^{I}$ Управление Роспотребнадзора по Еврейской автономной области, Биробиджан, Российская Федерация; \\ ${ }^{2}$ ФБУЗ «Центр гигиены и эпидемиологии в Еврейской автономной области», Биробиджан, Российская

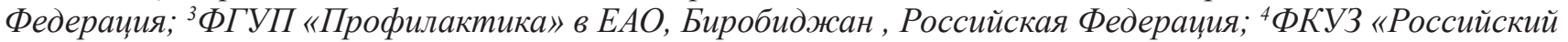 \\ научно-исследовательский противочумныий институт «Микроб», Саратов, Российская Федерачия; \\ ${ }^{5}$ ФУН «НИИ дезинфектологии», Москва, Российская Федерачия
}

\begin{abstract}
Дана количественная характеристика объектов Еврейской автономной области, подвергшихся подтоплению, показана необходимость проведения мероприятий по предупреждению обострения активности природных очагов геморрагической лихорадки с почечным синдромом на территории Еврейской автономной области. Представлены материалы по организации дератизационных мероприятий для профилактики природно-очаговых инфекций в паводковый и послепаводковый периоды 2013 г., данные об эффективности дератизации в различных административных районах субъекта, рассчитанные по формуле Аббота, результаты изучения заселенности мелкими грызунами природных стаций и обоснование проведения барьерной дератизации. Указаны площади проведения сплошной и барьерной дератизации, показатели инфицированности хантавирусами грызунов, отловленных во время проведения контроля эффективности дератизационных работ.
\end{abstract}

Ключевые слова: дератизация, природно-очаговые инфекции, грызуны.

\section{V.A.Yanovich ${ }^{1}$, E.S.Mironenko ${ }^{1}$, I.S.Butenko ${ }^{1}$, P.V.Kopylov ${ }^{2}$, I.P.Snetkova ${ }^{2}$, N.P.Shestopalov ${ }^{2}$, A.D.Vorontsova ${ }^{3}$, M.A.Tarasov ${ }^{4}$, V.M.Rusakov ${ }^{5}$}

\section{Deratization Activities in the Jewish Autonomous Region in the Post-Flooding Period}

${ }^{1}$ Rospotrebnadzor Administration in the Jewish Autonomous Region, Birobidzhan, Russian Federation; ${ }^{2}$ Center of Hygiene and Epidemiology in the Jewish Autonomous Region, Birobidzhan Russian Federation; ${ }^{3}$ State Federal Unitary Enterprise "Prophylaxis" in the Jewish Autonomous Region, Birobidzhan, Russian Federation; ${ }^{4}$ Russian Research Anti-Plague Institute "Microbe”, Saratov, Russian Federation; ${ }^{5}$ Research Institute of Disinfectology, Moscow, Russian Federation

Represented is a quantitative characteristic of the objects and facilities in the Jewish Autonomous Region exposed to the flooding-2013. Justified is the necessity for implementation of preventive measures against increase in the activity of HFRS natural foci; showed are the data on disinfestation organization for the prevention of natural-focal infection during the high water and post-flooding period in 2013. Displayed are the results of deratization efficacy control in various administrative units of the entity, calculated using Abbot formula, as well as results of investigation of small rodent population density at the natural stations and substantiation of the barrier disinfestation carrying out. Specified are the areas of the continuous and barrier disinfestation, indicators of Hanta Virus contamination of the rodents caught while performing control over efficacy of deratization works.

Key words: deratization, natural-focal infections, rodents.

В августе 2013 г. в результате катастрофического паводка на реке Амур и реках Еврейской автономной области в 6 муниципальных образованиях подверглись подтоплению 28 населенных пунктов из 111 (24,3\%) с населением 113070 чел. (60,7\% от общего числа населения области).

В 27 из них подверглось подтоплению 1541 (16,6 \% от общего числа) жилой дом с населением 6006 чел. (5,7\% от общего числа населения, проживающего в подтопленных населенных пунктах), в том числе 1326 детей (5,3%); 6924 приусадебных участка; 120 дачных участков; 330,665 кв. км сельскохозяйственных земель; 41 социально-значимый объект (3 объекта культуры, 24 котельных, 11 учреждений здравоохранения, 2 больницы, 9 ФАПов, 3 объекта образования); 1 скотомогильник; 5 кладбищ (села Квашнино, Новое, Кукелево Ленинского района, Нагибово Октябрьского района, Пашково Облученского района).

На территории Еврейской автономной области находятся природные очаги геморрагической лихорадки с почечным синдромом (ГЛПС), псевдотуберкулеза, лептоспироза, туляремии. Поэтому с учетом опыта наводнения 1984 г., в связи с реальной угрозой распространения природно-очаговых заболеваний организовано проведение дератизационных работ силами ФГУП «Профилактика» в ЕАО. Методическая и практическая помощь в организации и проведении дератизации была оказана специалистом Российского научно-исследовательского противочумного института «Микроб») и энтомологом Центра гигиены и эпидемиологии в ЕАО. На основании анализа многолетней заболеваемости сплошная дератизация проводилась в частном секторе в 25 населенных пун- 
ктах, подвергшихся затоплению, на территории 5058 усадьб площадью 3034800 кв.м.

По результатам контроля, эффективность дератизации, рассчитанная по формуле Аббота, составила в с. Пашково Облученского района (17.0918.09.2013 г.) - $100 \%$; п. Николаевка Смидовичского района (19.09-20.09.2013 г.) - $100 \%$; в селах Ленинское Ленинского района (21.09-22.09.2013 г.) $100 \%$; Амурзет Октябрьского района (23.0924.09.2013 г.) - 74,2 \%; Дубовое Биробиджанского района (25.09-26.09.2013) - $100 \%$.

Изучена заселенность в природных стациях: в 1,5 км от села Пашково - 1 попадание на 100 ловушко-суток (1,0\% попаданий); в 1,5 км от п. Николаевка (соевое поле) - 7,0\%; в 2-3 км от с. Ленинское - 22,1 \%; с. Амурзет - 48,0 \%; в 1,5-2 км от с. Дубовое - 30,0 \%.

Решение о проведении барьерной дератизации принималось по результатам ретроспективного анализа заболеваемости ГЛПС за 10 лет, данным исследований Хабаровской противочумной станции и СПЭБ-2 Иркутского противочумного института. Были выбраны населенные пункты для барьерной дератизации (13 - как первоочередные) с высоким уровнем заболеваемости в предыдущие годы. Общая площадь барьерной дератизации составила 9200000 кв.м.

После барьерной дератизации (с 24 по 29 сентября 2013 г.) в октябре проведен контроль ее эффективности: п. Николаевка обилие мелких млекопитающих составило 1 \% попаданий (домовая мышь), в сентябре - 4 \%; с. Дубовое - 8 \% (4 серых крысы, 4 мыши, в том числе 1 домовая); с. Амурзет - $8 \%$ (7 домовых мышей, 1 полевая мышь), в сентябре - $22 \%$; с. Ленинское - 4 \% (3 домовых мыши, 1 мышь полевая), в сентябре - $10 \%$. На основании полученных данных проведена повторная сплошная и барьерная дератизация в с. Амурзет.

Отловленные во время проверки эффективности дератизации грызуны доставлены для изучения их инфицированности возбудителями зооантропонозов в Хабаровскую противочумную станцию. 146 экземпляров мелких млекопитающих 8 видов, в том числе 80 полевых мышей, исследованы на зараженность хантавирусами непрямым методом флюоресцирующих антител (НМФА). Носителями хантавирусов оказались 12 зверьков 3 видов: 7 полевых мышей, 2 восточноазиатские мыши и одна красная полевка, в двух из семи населенных пунктах (с. Дубовое и с. Амурзет). Показатель инфицированности со- ставил 8,3\%, в том числе полевой мыши - 8,7\% (с. Дубовое - 14,3 \% и с. Амурзет - 13,5 \%).

21 ноября 2013 г. получены результаты исследования грызунов, проведенные на базе Хабаровской противочумной станции: из 21 пробы выявлена одна с положительным результатом на зараженность хантавирусами (серая крыса отловлена в с. Дубовое).

Для проведения работ по дератизации Федеральной службой по надзору в сфере защиты прав потребителей и благополучия человека был направлен специалист НИИ дезинфектологии (Москва), бортом МЧС доставлено 284 л ядов (броммед, брумус, бромцидфлюид).

Дополнительно Центром гигиены и эпидемиологии в Приморском крае и Хабаровской дезинфекционной станцией безвозмездно предоставлено 14 кг бромадиалона и фосфида цинка, 100 кг готовой приманки.

На проведение дератизационных работ решениями Комиссии по предупреждению и ликвидации чрезвычайных ситуаций и обеспечению пожарной безопасности правительства ЕАО выделено 502777 тыс. рублей. Считаем, что комплекс систематически проводимых мероприятий по дератизации позволил сдержать численность грызунов и, соответственно, стабилизировать заболеваемость ГЛПС на уровне среднемноголетних показателей.

Authors:

Yanovich V.A., Mironenko E.S., Butenko I.S. Rospotrebnadzor Administration in the Jewish Autonomous Region. 17, Sholom-Aleykhem St., Birobidzhan, 679016, Russian Federation. E-mail: zpp@79.rospotrebnadzor Kopylov P.V., Snetkova I.P., Shestopalov N.P. Center of Hygiene and Epidemiology in the Jewish Autonomous Region. 17, Sholom-Aleykhem St., Birobidzhan,679016, Russian Federation. E-mail: gigepid@mail.ru Vorontsova A.D. State Federal Unitary Enterprise "Prophylaxis" in the Jewish Autonomous Region. Birobidzhan, Russian Federation.

Tarasov M.A. Russian Research Anti-Plague Institute "Microbe". 46 Universitetskaya St., Saratov, 410005, Russian Federation. E-mail: rusrapi@ microbe.ru

Rusakov V.M. Research Institute of Disinfectology. 18, Nauchny proezd, Moscow, 117246, Russian Federation. E-mail: info@niid.ru

Об авторах:

Янович В.А., Мироненко Е.С., Бутенко И.С. Управление Роспотребнадзора по Еврейской автономной области. Российская Федерация, 679016, Биробиджан, ул. Шолом-Алейхема, 17. E-mail: zpp@79.rospotrebnadzor.ru

Копылов П.В., Снеткова И.П., Шестопалов Н.П. Центр гигиены и эпидемиологии в Еврейской автономной области. Российская Федерация 679016, Биробиджан, ул. Шолом-Алейхема, 17. E-mail: gigepid@mail.ru Воронцова А.Д. ФГУП «Профилактика» в ЕАО. Российская Федерация, Еврейская автономная область, с. Птичник ул. Кооперативная, 3 a.

Тарасов М.А. Российский научно-исследовательский противочумный институт «Микроб». Российская Федерация, 410005, Саратов, ул. Университетская, 46. E-mail: rusrapi@microbe.ru

Русаков В.М. НИИ дезинфектологии. Российская Федерация, 117246, Москва, Научный проезд, 18. E-mail: info@niid.ru 